\title{
NO in exhaled air is correlated with markers of eosinophilic air- way inflammation in corticosteroid-dependent childhood asthma
}

\author{
J. Mattes*, K. Storm van's Gravesande*, U. Reining*, K. Alving ${ }^{+}$, G. Ihorst*, M. Henschen*, J. Kuehr*
}

NO in exhaled air is correlated with markers of eosinophilic airway inflammation in corticosteroid-dependent childhood asthma. J. Mattes, K. Storm van's Gravesande, U. Reining, K. Alving, G. Ihorst, M. Henschen, J. Kuehr. CERS Journals Ltd 1999.

ABSTRACT: The relationship between nitric oxide in exhaled air, levels of sputum eosinophils, sputum eosinophil cationic protein (ECP) and urinary eosinophil protein $X(E P X)$ excretion has not yet been investigated in corticosteroid-dependent childhood asthma.

Therefore, taking 25 children with stable asthma (mean age 11.2 yrs) treated with inhaled corticosteroids and nine nonatopic healthy control children (mean age 12.8 yrs) the level of exhaled NO was measured by means of a chemiluminescence analyser before and after sputum induction. This was conducted as a slow vital capacity manoeuvre under standardized conditions with a target flow of $70 \mathrm{~mL} \cdot \mathrm{s}^{-1}$ against a resistance of $100 \mathrm{cmH}_{2} \mathrm{O} \cdot \mathrm{L}^{-1} \cdot \mathrm{s}$. Sputum induction was performed by inhalation of hypertonic saline $(3,4$, and $5 \%)$ in a standardized manner and a single sample of urine was collected.

Exhaled NO ( $p=0.01$ ), absolute eosinophil cell counts in sputum ( $p=0.02)$, sputum ECP $(p=0.09)$ and urinary EPX excretion $(p=0.02)$ were higher in asthmatics compared to control children. Exhaled NO was positively correlated with sputum ECP $\left(r_{s}=0.59, p=0.002\right)$, urinary EPX $\left(r_{s}=0.42, p=0.03\right)$, and sputum eosinophils $\left(r_{s}=0.30\right.$, $p=0.15$ ) in the asthmatic children. These correlations appeared to be pronounced after sputum induction, where NO values had decreased $(p=0.01)$. None of the correlations were observed in the group of nonatopic control subjects. Additionally there were significant correlations between sputum ECP and sputum eosinophils $\left(r_{s}=0.69, p<\right.$ $0.001)$ as well as between sputum ECP and urinary EPX excretion $\left(r_{s}=0.58, p=0.003\right)$ in the asthmatics.

Exhaled NO provides information about the degree of eosinophilic airway inflammation and thus appears to be a useful and easy-to-perform inflammatory marker in corticosteroid-dependent asthma.

Eur Respir J 1999; 13: 1391-1395.
*University Children's Hospital, Freiburg, Germany. ${ }^{+}$Karolinska Institute, Dept of Physiology and Pharmacology, Stockholm, Sweden.

Correspondence: J. Mattes

University Children's Hospital Freiburg Mathildenstrasse 1

79106 Freiburg

Germany

Fax: 497612704450

Keywords: Asthma

eosinophil cationic protein

eosinophil protein $\mathrm{X}$

eosinophils

exhaled nitric oxide

induced sputum

Received: November 111998

Accepted after revision March 151999
It is suggested that eosinophilic inflammation is a hallmark of bronchial asthma [1]. Measurement of markers released by eosinophils, such as eosinophil cationic protein (ECP) in sputum and urinary eosinophil protein $\mathrm{X}$ (EPX) offer the prospect of relating airway inflammation to clinical features and treatment response $[2,3]$. In recent years several studies have focused on nitric oxide as an alternative indicator of inflammatory activity in asthma [4]. In airway inflammation, NO is released by a calciumindependent inducible NO synthase (iNOS) and can be detected in exhaled air [5,6]. In sputum samples of asthmatics, increased levels of ECP are closely correlated to the concentration of nitrite and nitrate, the stable end products of NO metabolism [7]. Recently JATAKANON et al. [8] demonstrated a relationship between exhaled NO and sputum eosinophils in asthmatics not using inhaled corticosteroids. Since the expression of iNOS is inhibited by corticosteroids [9], it is not yet clear whether exhaled NO gives information about the degree of eosinophilic airway inflammation in asthmatics treated with inhaled corticosteroids [8]. However, the influence of asthma therapy on markers of airway inflammation is of practical relevance. The quantitative relationship between exhaled NO and reference markers of airway inflammation (sputum eosinophils, sputum ECP, urinary EPX) were therefore investigated in asthmatic children treated with inhaled corticosteroids and in nonatopic control subjects.

\section{Methods}

\section{Population}

Twenty-five children with stable asthma who had been taking inhaled corticosteroids $\left(400-800 \mu \mathrm{g} \cdot \mathrm{day}^{-1}\right.$ budesonide) regularly for at least 6 months were recruited from the outpatients department of the University Children's Hospital. The initial diagnosis of asthma was based upon clinical symptoms of asthma (e.g., episodic cough, wheezing, and/or dyspnoea) and an increase of $\geq 15 \%$ in the forced expiratory volume in one second (FEV1) in response to bronchodilator in accordance with the American Thoracic Society criteria [10]. Of the 25 asthmatic children, 24 were sensitized to common inhalant allergens (skin prick test). Children were asked to withhold the use 
of bronchodilator and corticosteroids for $12 \mathrm{~h}$ before the visit. Additionally, nine children without atopic disorders (asthma, hay fever, and eczema) and no sensitization to common inhalant allergens (skin prick test) and no history of parental asthma were recruited. Mean age of the 25 children with asthma was 11.2 yrs (range 6-16 yrs, four females) and $12.8 \mathrm{yrs}$ in the nine nonatopic children (range 8-18 yrs, eight females). All measurements were prospectively performed at the same time of day (14:0017:00 h). The study was approved by the ethics committee of the Albert-Ludwigs University, Freiburg, and written informed consent was obtained in advance.

\section{Spirometry}

All children underwent spirometry according to international guidelines [11]. Briefly, the highest FEV1 of two reproducible flow volume curves (difference between forced vital capacities (FVC) $\leq 5 \%$ ) was recorded by using a Masterscope 4.0 (Jaeger, Würzburg, Germany). FEV1 was presented as a percentage of predicted value for each child's height and weight [12].

\section{Measurement of exhaled nitric oxide}

Exhaled NO was measured before and after sputum induction during a single-breath exhalation by means of a computerized system for online recordings (Exhaled Breath Analyser, Aerocrine AB, Stockholm, Sweden) with a chemiluminescence analyser (CLD 77 AM; Eco Physics, Duernten, Switzerland). The analyser has a response time of $100 \mathrm{~ms}$ and a detection limit of 0.1 parts per billion (ppb). Measurements were made according to European Respiratory Society recommendations [13]. In brief, twopoint calibrations ( 80 parts per million NO balanced with $\mathrm{N}$ ) and $\mathrm{NO}$ zeroing (NO-free air) were performed before the measurements. Children inhaled NO-free air to avoid contamination with ambient NO [14], and performed a slow vital capacity (VC) manoeuvre with a target flow of $70 \mathrm{~mL} \cdot \mathrm{s}^{-1}$. The flow was measured by a heated pneumotachograph (Hans Rudolph, Kansas City, MO, USA) and displayed online to provide visual guidance and maintain the exhalation flow. A fixed expiratory resistance of 100 $\mathrm{cmH}_{2} \mathrm{O} \cdot \mathrm{L}^{-1} \cdot \mathrm{s}$ (Hans Rudolph) was used to increase oral pressure. This was shown to prevent contamination with NO from the nasopharynx [15]. Exhaled air was led via a nonrebreathing valve (Hans Rudolph) into a Teflon tubing system connected to the analyser and continuously sampled from the exhalation limb of the system. After a 15-20-s period of exhalation, mean NO concentration and flow were calculated from the $60-90 \%$ part of the exhalation corresponding to the plateau level of NO concentration [13], and NO output (in pmol. $\mathrm{s}^{-1}$ ) was calculated from these values. VC manoeuvres were made at 2-min intervals before and after sputum induction and the mean of two reproducible readings (i.e. variation coefficient $<15 \%$ ) was used for analysis as calculation of median and $90 \%$ intervals.

\section{Sputum induction}

Sputum induction was performed as previously described by PIN et al. [16]. Briefly, 10 min after inhalation of $200 \mu \mathrm{g}$ salbutamol subjects inhaled hypertonic saline (3, 4 and 5\%) via an ultrasonic nebulizer (Ultraneb 2000; DeVilbiss, Somerset, PA, USA) with the output set at maximum $\left(4.5 \mathrm{~mL} \cdot \mathrm{min}^{-1}\right)$ for three consecutive periods of $10 \mathrm{~min}$ for each concentration. Lung function was tested before the procedure and every $5 \mathrm{~min}$ during it. To produce sputum, subjects were asked to rinse their mouths, blow their noses, swallow water, and then to expectorate the sputum onto a plastic petri dish after the first $10 \mathrm{~min}$ period of inhalation and every 5 min thereafter. During the induction procedure macroscopic characteristics of the sputum were recorded [16] and adequate plugs of sputum were selected to reduce contamination with saliva and processed immediately after inhalation [17].

\section{Sputum processing}

The weight of the selected plugs was determined and twice their volume of dithiothreitol $0.1 \%$ (Sputalysin; Calbiochem, Bad Soden, Germany) was added [18]. The samples were mixed gently by a vortex mixer and placed in a water bath at $37^{\circ} \mathrm{C}$ for $15 \mathrm{~min}$ to ensure complete homogenization. The samples were removed from the water bath periodically for further brief gentle vortex mixing. Afterwards phosphate-buffered saline (PBS) was added to the samples to achieve a 20 -fold final dilution [18]. The samples were centrifuged at $600 \times g$ and $4^{\circ} \mathrm{C}$ for $10 \mathrm{~min}$ and supernatants were collected from plugs and saliva. The material was stored at $-70^{\circ} \mathrm{C}$ until further analysis. Cells of the selected plugs were resuspended in PBS - bovine serum albumin (BSA) (1\%), and absolute counts of nonsquamous cells were measured in a haemocytometer. Viability was determined by trypan blue exclusion. A portion of $3-6 \times 10^{4}$ cells was used to prepare cytospin glass slides (Shandon cytocentrifuge 3; Shandon Southern Instruments, Sewickley, PA, USA). Differential cell counting was carried out by one experienced investigator on cytospins stained with May-GrünwaldGiemsa, and at least 400 nonsquamous cells were counted. Results of eosinophilic cell counts were expressed as absolute cell counts.

\section{Analysis of sputum supernatants and urine}

Using the Pharmacia CAP system (ECP FEIA; Pharmacia \& Upjohn, Freiburg, Germany) ECP was analysed in the supernatants of the selected plugs. A single, nonselectively collected sample of urine was collected and immediately frozen at $-70^{\circ} \mathrm{C}$. Levels of urinary EPX were measured with a double antibody radioimmunoassay (Pharmacia \& Upjohn). Measurement of urine creatinine was carried out by using the alkaline picrate method (Jaffé reaction) [19]. Results of urinary EPX excretion were presented in $\mu \mathrm{g} \cdot \mathrm{mmol}$ creatinine ${ }^{-1}$.

\section{Statistical analysis}

Exhaled NO concentration, NO output, absolute eosinophil cell counts in sputum, levels of sputum ECP and urinary EPX excretion were calculated as median with $90 \%$ intervals. ECP levels below the detection limit of 2 
$\mu \mathrm{g} \cdot \mathrm{L}^{-1}$ (diluted sample: $40 \mu \mathrm{g} \cdot \mathrm{L}^{-1}$ ) in four children (two asthmatics and two control subjects) were set at $1.99 \mu \mathrm{g} \cdot \mathrm{L}^{-1}$ (diluted sample: $39.8 \mu \mathrm{g} \cdot \mathrm{L}^{-1}$ ). Comparison of values between asthmatic and nonatopic children were performed using the Wilcoxon two sample test. Comparison of NO levels before and after sputum induction was carried out by using the Wilcoxon sign rank test. The relation between the variables was calculated using Spearman's rank-correlation coefficients. A p-value of $<0.05$ was considered significant. Analysis was performed with the Statistical Analysis System (SAS Institute, Cary, NC, USA).

\section{Results}

Exhaled NO and NO output before bronchodilator application and sputum induction were higher in children with asthma compared to control subjects (table $1, \mathrm{p}=$ $0.01)$. After sputum induction, NO concentration and NO output decreased in the asthmatic and the nonatopic children, whereas the flow did not change substantially (table 1). While levels of sputum ECP were not significantly different between the two groups (table 1 , $\mathrm{p}=0.09$ ), the absolute eosinophilic cell counts in sputum were significantly higher in children with asthma compared to control subjects (table $1, \mathrm{p}=0.02$ ). In addition, urinary EPX excretion was significantly higher in asthmatics (table $1, \mathrm{p}=0.02$ ), whereas $\mathrm{FEV} 1 \%$ predicted was significantly lower compared to nonatopic children (table $1, \mathrm{p}=0.02$ ).

No significant difference between the asthmatic and the nonatopic children was observed for the total cell counts (median $\left(90 \%\right.$ intervals) $1.61 \times 10^{6}$ cells $\left(0.29 \times 10^{6}-\right.$ $\left.4.48 \times 10^{6}\right)$ versus $1.44 \times 10^{6}$ cells $\left(0.33 \times 10^{6}-3.30 \times 10^{6}\right)$, $\mathrm{p}=0.31)$, weight of the selected plugs $(74.0 \mathrm{mg}(28.5-$ $306.9)$ versus $49.8 \mathrm{mg}(30.4-103.7), \mathrm{p}=0.17)$ and the percentage of viable nonsquamous cells $(91 \%(70-100)$ versus $90 \%(76-100), \mathrm{p}=0.9)$. In one subject sputum induction could not be performed because of an FEV1 $<80 \%$ pred. None of the remaining 33 children experienced discomfort or a fall in baseline FEV1 exceeding $15 \%$ during sputum induction.

The NO concentration (before sputum induction) showed a significant correlation with sputum ECP in the asthmatics (fig. $1, \mathrm{r}_{\mathrm{s}}=0.59, \mathrm{p}=0.002$ ), but not in the control subjects $\left(r_{s}=-0.48, p=0.19\right)$. The correlation between exhaled NO levels and absolute eosinophil cell counts was not significant in children with asthma $\left(r_{s}=0.30\right.$,

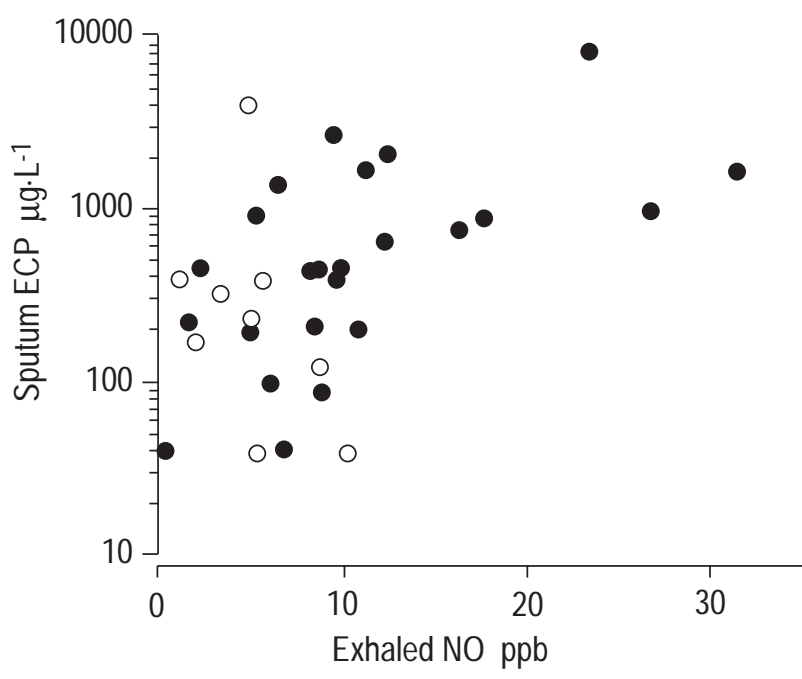

Fig. 1. - Correlation between the concentration of exhaled nitric oxide (in parts per billion (ppb)) and the levels of sputum eosinophil cationic protein $\left(\mathrm{ECP}\right.$; in $\mu \mathrm{g} \cdot \mathrm{L}^{-1}$, on a $\log$ scale) in asthmatic $(\mathrm{O} ; \mathrm{n}=24)$ and nonatopic $(O ; n=9)$ children. For asthmatic children $r_{s}=0.59, p=0.002$ and nonatopic children $r_{s}=-0.48, p=0.19$.

$\mathrm{p}=0.15)$. NO values (before sputum induction) showed weaker, yet significant positive correlations with urinary EPX excretion in the asthmatics (fig. 2, $\mathrm{r}_{\mathrm{s}}=0.42$, $\mathrm{p}=0.03$ ), but not in the control group $\left(\mathrm{r}_{\mathrm{s}}=0.23, \mathrm{p}=0.55\right)$.

All correlations were more pronounced in the asthmatics after sputum induction (correlation between $\mathrm{NO}$ values and sputum ECP $\mathrm{r}_{\mathrm{s}}=0.65, \mathrm{p}<0.001$; correlation between NO values and sputum eosinophils $r_{s}=0.35, p=0.09$; correlation between NO values and urinary EPX $\mathrm{r}_{\mathrm{s}}=0.54, \mathrm{p}=0.007$ ). The same significant correlations were found between NO output and eosinophilic markers in the asthmatics, but not in the control group (data not shown). Sputum ECP and urinary EPX excretion were positively correlated in asthmatics $\left(\mathrm{r}_{\mathrm{s}}=0.58, \mathrm{p}=0.003, \mathrm{n}=24\right)$ but not in the control group $\left(\mathrm{r}_{\mathrm{s}}=-0.32, \mathrm{p}=0.40, \mathrm{n}=9\right)$. In addition sputum ECP was significantly correlated with the absolute eosinophil cell counts in the asthmatics $\left(\mathrm{r}_{\mathrm{s}}=0.69, \mathrm{p}=0.0002\right)$.

\section{Discussion}

These data show for the first time that in asthmatic patients treated with inhaled corticosteroids, exhaled NO is

Table 1. - Exhaled NO concentration and flow before and after sputum induction, absolute eosinophil cell counts in sputum, levels of sputum eosinophil cationic protein (ECP) and urinary eosinophil protein X (EPX) excretion in asthmatic and nonatopic children

\begin{tabular}{|c|c|c|c|c|c|c|c|c|c|c|}
\hline & \multicolumn{2}{|c|}{ NO concentration $\mathrm{ppb}$} & \multicolumn{2}{|c|}{ NO output pmol. $\mathrm{s}^{-1}$} & \multicolumn{2}{|c|}{ Flow $\mathrm{mL} \cdot \mathrm{s}^{-1}$} & \multirow{2}{*}{$\begin{array}{l}\text { Absolute } \\
\text { - eosinophil } \\
\text { cell counts }\end{array}$} & \multirow{2}{*}{$\begin{array}{c}\text { Sputum ECP } \\
\mu \mathrm{g} \cdot \mathrm{L}^{-1}\end{array}$} & \multirow{2}{*}{$\begin{array}{c}\text { Urinary EPX } \\
\text { excretion } \\
\mu \mathrm{g} \cdot \mathrm{mmol} \\
\text { creatinine }^{-1}\end{array}$} & \multirow{2}{*}{$\begin{array}{l}\text { FEV1 } \\
\% \text { pred }\end{array}$} \\
\hline & Before & After & Before & After & Before & After & & & & \\
\hline $\begin{array}{l}\text { Asthmat } \\
\text { childre }\end{array}$ & $\begin{array}{c}9.7 \\
(1.8-27.0)^{* *}\end{array}$ & $\begin{array}{c}7.9 \\
(1.3-26.7)^{* *}\end{array}$ & $\begin{array}{c}24.9 \\
(4.7-71.4)^{* *}\end{array}$ & $\begin{array}{c}20.5 \\
(3.3-73.2)^{* *}\end{array}$ & $=\begin{array}{c}65 \\
(59-74)\end{array}$ & $\begin{array}{c}67 \\
(57-72)\end{array}$ & $\begin{array}{c}35.4 \times 10^{3} \\
(6.9-179.0)\end{array}$ & $\begin{array}{c}453.0 \\
(<40-2600)\end{array}$ & $\begin{array}{c}58.2 \\
(29.2-181.1)\end{array}$ & $\begin{array}{c}96 \\
(76-131)\end{array}$ \\
\hline $\begin{array}{l}\text { Nonatopic } \\
\text { children }\end{array}$ & $\begin{array}{c}5.2 \\
(0.1-10.4)^{\#}\end{array}$ & $\begin{array}{c}4.1 \\
(0.7-7.5)^{\#}\end{array}$ & $\begin{array}{c}14.6 \\
(4.6-28.8)^{\#}\end{array}$ & $\begin{array}{c}11.6 \\
(2.1-20.2)^{\#}\end{array}$ & $\begin{array}{c}68 \\
(59-87)\end{array}$ & $\begin{array}{c}69 \\
(59-73)\end{array}$ & $\begin{array}{l}5.8 \times 10^{3} \\
(0-54.0)\end{array}$ & $\begin{array}{c}234.0 \\
(<40-4000)\end{array}$ & $\begin{array}{c}30.6 \\
(20.8-75.5)\end{array}$ & $\begin{array}{c}113 \\
(99-124)\end{array}$ \\
\hline p-value ${ }^{+}$ & 0.01 & 0.04 & 0.01 & 0.05 & 0.22 & 0.22 & 0.02 & 0.09 & 0.02 & 0.02 \\
\hline
\end{tabular}

Data are presented as medians with $90 \%$ intervals in parentheses. ppb: Parts per billion; FEV1: forced expiratory volume in one second. ${ }^{+}$: differences between the two groups; **: $\mathrm{p}=0.01$, for the difference between the NO concentration and NO output before and after sputum induction; ${ }^{\#}: \mathrm{p}=0.07$, for the difference between the NO concentration and NO output before and after sputum induction. 


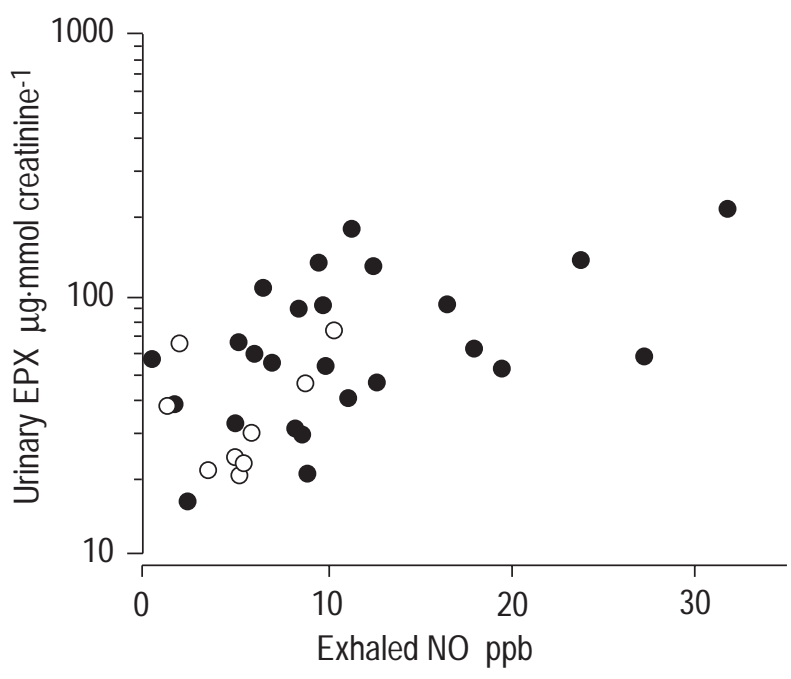

Fig. 2. - Correlation between the concentration of exhaled nitric oxide (in parts per billion (ppb)) and the levels of urinary eosinophil protein $\mathrm{X}$ excretion (EPX; in $\mu \mathrm{g} \cdot \mathrm{mmol}$ creatinine $^{-1}$, on a log scale) in asthmatic $(O ; n=25)$ and nonatopic $(\bigcirc ; n=9)$ children. For asthmatic children $\mathrm{r}_{\mathrm{s}}=0.42, \mathrm{p}=0.03$ and nonatopic children $\mathrm{r}_{\mathrm{s}}=0.23, \mathrm{p}=0.55$.

significantly related to sputum ECP and urinary EPX, but weaker with regard to sputum eosinophils. Additionally, there are significant correlations between sputum ECP and both sputum eosinophils and urinary EPX, reflecting consistently the presence of eosinophilic inflammation in the asthmatic patients.

The comparison of NO exhalation before and after bronchodilator application and sputum induction suggests that the decrease in $\mathrm{NO}$ concentration is associated with the decrease in NO output, but not with a change in flow. It remains unclear whether the decrease of exhaled NO was due to inhalation of hypertonic saline as reported by $\mathrm{DE}$ Gouw et al. [20], or due to repeated spirometry during sputum induction as reported by DEYKIN et al. [21]. It was hypothesized that the decrease in exhaled NO concentration could be an effect of changes in airway calibre [20]. However, in the present study no correlation between exhaled NO and dynamic lung function parameters such as $\mathrm{FEV}_{1} \%$ pred was observed (data not shown). A further explanation for the systematic decrease in NO levels might be the rinsing of the mouth and swallowing of water, since salivary NO formation has been shown to contribute to exhaled NO levels [22]. This hypothesis is in accordance with the further pronounced correlations between eosinophilic markers and NO values measured directly after sputum induction. Nevertheless, it remains unclear whether initial rinsing of the mouth is a necessary step to standardize NO measurements.

Earlier studies suggested that neither measuring exhaled NO nor measuring eosinophilic markers in sputum and urinary EPX excretion allowed a sufficient discrimination between stable asthmatic children using inhaled corticosteroids and nonatopic children [23-25]. The present data show that exhaled NO levels, urinary EPX excretion, and sputum eosinophils were significantly higher in asthmatics compared to nonatopic children. Since these patients were under stable conditions without a history of an acute exacerbation in the previous month, it appears probable that the inhaled corticosteroids were regularly used.
Therefore, although there was no direct measure of eosinophilic airway inflammation in tissue (biopsies), the significant difference in the sputum eosinophil cell counts suggests a substantially higher degree of inflammation in corticosteroid-treated asthmatics compared to control subjects.

A significant correlation was observed between exhaled $\mathrm{NO}$ and the reference parameters sputum ECP and urinary EPX excretion in asthmatics (figs. 1 and 2). As expected, sputum ECP was positively correlated with sputum eosinophils and with urinary EPX excretion in the asthma group. The relation between exhaled NO and sputum ECP found in this study was not substantially different from the relation between sputum NO derivates (nitrite and nitrate) and levels of sputum ECP $\left(\mathrm{r}_{\mathrm{s}}=0.56, \mathrm{p}<0.05\right.$, $\mathrm{n}=18$ ) recently described in adults with asthma [7]. A significant correlation between exhaled $\mathrm{NO}$ and sputum eosinophils has been observed in adults with mild asthma undergoing treatment with $\beta$-agonists only $\left(r_{s}=0.48\right.$, $\mathrm{p}<0.05, \mathrm{n}=35$ ) [8], whereas in the present study only a weak correlation was found between exhaled NO and sputum eosinophils in children with corticosteroid-dependent asthma. However, besides treatment with steroids other influences such as asthma severity and age-related factors could have caused the quantitative difference in correlation between the two studies. Nevertheless, as the expression of iNOS is inhibited by corticosteroids [9], these correlations could potentially be more pronounced in asthmatic children without such medication.

One basis for understanding the correlations between exhaled NO and eosinophilic markers is the observation that murine T-helper 1 cell clones produce NO following activation, and that NO inhibits the cytokine production of T-helper 1, but not T-helper 2 T-cell clones [26]. In accordance with these findings, nitric oxide synthase-deficient mice showed an enhanced T-helper 1, but an impaired T-helper 2 immune response following antigen stimulation [27]. The consecutive release of T-helper 2associated cytokines such as interleukin-5 could then contribute to the recruitment of eosinophils and the release of eosinophilic markers into the airways. Thus, the correlation between exhaled NO and markers of eosinophilic inflam-mation in bronchial asthma might be based on a causal link [28]. Alternatively, NO production and eosinophil recruitment might be under the same transcriptional control, since both inducible nitric oxide synthase and cytokines involved in eosinophil differentiation (e.g. granulocyte-macrophage colony-stimulating factor) are regulated by the glucocorticoid-sensitive transcriptional nuclear factor $\kappa-\mathrm{B}[29]$. In conclusion, the present data suggest that exhaled NO provides information about the degree of eosinophilic activation in children with stable asthma treated with inhaled corticosteroids. Thus, exhaled NO appears to be a useful and easy-to-perform inflammatory marker in corticosteroid-dependent asthma.

\section{References}

1. Bousquet J, Chaez P, Lacoste JY, et al. Eosinophilic inflammation in asthma. N Engl J Med 1990; 323: 10331039. 
2. Pavord ID, Pizzichini MMM, Pizzichini E, Hargreave FE. The use of induced sputum to investigate airway inflammation. Thorax 1997; 52: 498-501.

3. Kristjansson S, Strannegard IL, Wennergren G. Inflammatory markers in childhood asthma. Ann Med 1996; 28: 395-399.

4. Lundberg JON, Lundberg JM, Alving K, Weitzberg E. Nitric oxide and airway inflammation: the answer is blowing in the wind. Nat Med 1997; 13: 30-31.

5. Alving K, Weitzberg E, Lundberg JM. Increased amount of nitric oxide in exhaled air of asthmatics. Eur Respir $J$ 1993; 6: 1368-1370.

6. Kharitonov SA, Yates DH, Robbins RA, Logan-Sinclair $\mathrm{R}$, Shinebourne EA, Barnes PJ. Increased nitric oxide in exhaled air of asthmatic patients. Lancet 1994; 343: 133135.

7. Kanazawa H, Shoji S, Yamada M, et al. Increased levels of nitric oxide derivates in induced sputum in patients with asthma. J Allergy Clin Immunol 1997; 99: 624 629.

8. Jatakanon A, Lim S, Kharitonov SA, Chung KF, Barnes PJ. Correlation between exhaled nitric oxide, sputum eosinophils, and methacholine responsiveness in patients with mild asthma. Thorax 1998; 53: 91-95.

9. Knowles RG, Salter M, Brooks SL, Moncada S. Antiinflammatory glucocorticosteroids inhibit the induction by endotoxin of nitric oxide synthase in the lung, liver and aorta of the rat. Biochem Biophys Res Commun 1990; 172: $1042-1048$.

10. American Thoracic Society. Standards for the diagnosis and care of patients with chronic obstructive pulmonary disease (COPD) and asthma. Am Rev Respir Dis 1987; 136: 225-244.

11. American Thoracic Society. Standardization of spirometry. Am Rev Respir Dis 1987; 136: 1285-1298.

12. Zapletal A. Lung function in children and adolescents. In: Herzog H, ed. Progress in Respiration Research. Basel, Karger, 1987; pp. 173-196.

13. Kharitonov SA, Alving K, Barnes PJ. Exhaled and nasal nitric oxide measurements: recommendations (ERS Task Force Report). Eur Respir J 1997; 10: 1683-1693.

14. Therminarias A, Flore P, Favre-Juvin A, Oddou M-F, Delaire M, Grimbert F. Air contamination with nitric oxide: effect on exhaled nitric oxide response. $\mathrm{Am} J$ Respir Crit Care Med 1998: 157: 791-795.

15. Silkoff PE, McClean PA, Slutzky AS, et al. Marked flowdependence of exhaled nitric oxide using a new technique to exclude nasal nitric oxide. Am J Respir Crit Care Med 1997; 155: 260-267.
16. Pin I, Gibson PG, Kolendowicz R, et al. Use of induced sputum cell counts to investigate airway inflammation in asthma. Thorax 1992; 47: 25-29.

17. Gershman NH, Wong HH, Liu JT, Mahlmeister MJ, Fahy JV. Comparison of two methods of collecting induced sputum in asthmatic subjects. Eur Respir $J$ 1996; 9: 2448-2453.

18. Holz O, Joerres RA, Koschyk S, Speckin P, Welker L, Magnussen $\mathrm{H}$. Changes in sputum composition during sputum induction in healthy and asthmatic subjects. Clin Exp Allergy 1998; 28: 284-292.

19. Apple F, Brandt C, Prosch A, et al. Creatinine clearance: enzymatic versus Jaffé determination of creatinine in plasma and urine. Clin Chem 1986; 32: 388-390.

20. De Gouw HWFM, Hendriks J, Woltman AM, Twiss IM, Sterk PJ. Exhaled nitric oxide (NO) is reduced shortly after bronchoconstriction to direct and indirect stimuli in asthma. Am J Respir Crit Care Med 1998; 158: 315-319.

21. Deykin A, Halpern O, Massaro AF, Drazen JM, Israel E. Expired nitric oxide after bronchoprovocation and repeated spirometry in patients with asthma. Am J Respir Crit Care Med 1998; 157: 769-775.

22. Zetterquist W, Pedroletti C, Lundberg JON, Alving K. Salivary contribution to exhaled nitric oxide. Eur Respir J 1998; 13: 327-333.

23. Dupont LJ, Rochette F, Demedts MG, Verleden GM. Exhaled nitric oxide correlates with airway hyperresponsiveness in steroid-naive patients with mild asthma. Am J Respir Crit Care Med 1998; 157: 894-898.

24. Sorva R, Metso T, Turpeinen M, Juntunen-Backman K, Bjoerkstén F, Haahtela T. Eosinophil cationic protein in induced sputum as a marker of inflammation in asthmatic children. Pediatr Allergy Immunol 1997; 8: 45-50.

25. Kristjansson S, Strannegard IL, Strannegard O, Peterson C, Enander I, Wennergren G. Urinary eosinophil protein $\mathrm{X}$ in children with atopic asthma: a useful marker of antiinflammatory treatment. J Allergy Clin Immunol 1996; 97: 1179-1187.

26. Taylor-Robinson AW, Liew FY, Severn A, et al. Regulation of the immune response by nitric oxide differentially produced by $\mathrm{T}$ helper type 1 and $\mathrm{T}$ helper type 2 cells. Eur J Immunol 1994; 24: 980-984.

27. Wie XQ, Charles IG, Smith A, et al. Altered immune response in mice lacking inducible nitric oxide synthase. Nature 1995; 375: 408-411.

28. Barnes PJ, Liew FY. Nitric oxide and asthmatic inflammation. Immunol Today 1995; 16: 128-129.

29. Barnes PJ. Molecules in focus: nuclear factor- $\kappa \mathrm{B}$. Int $J$ Biochem Cell Biol 1997; 29: 867-870. 